\title{
1 Triple oxygen and hydrogen isotopes of gypsum hydration water for
}

\section{quantitative paleo-humidity reconstruction}

4 Fernando Gázquez $^{1 *}$, Mario Morellón ${ }^{2}$, Thomas Bauska ${ }^{1}$, Daniel Herwartz ${ }^{3}$, Jakub Surma ${ }^{3}$, Ana

5 Moreno $^{4}$, Michael Staubwasser ${ }^{3}$, Blas Valero-Garcés ${ }^{4}$, Antonio Delgado-Huertas ${ }^{5}$ and David A.

Hodell $^{1}$

${ }^{1}$ Godwin Laboratory for Palaeoclimate Research. Department of Earth Sciences. University of Cambridge. Downing Street, Cambridge, CB2 3EQ, United Kingdom

${ }^{2}$ CITIMAC, Facultad de Ciencias. University of Cantabria. Avenida de los Castros s/n, 39005, Santander,

${ }^{3}$ Institute für Geology und Mineralogy. Universität zu Köln. Greinstrasse. 4-6, 50939, Köln, Germany.

${ }^{4}$ Department of Environmental Processes and Global Change, Pyrenean Institute of Ecology (IPE) CSIC, Campus de Aula Dei, Avenida Montañana, 1005, E-50059, Zaragoza, Spain. ${ }^{5}$ Laboratorio de Biogeoquímica de Isotopos Estables, Instituto Andaluz de Ciencias de la Tierra IACT (CSIC-UGR). Avda. de las Palmeras, 4, 18100, Armilla, Granada, Spain

*now at School of Earth and Environmental Sciences. University of St. Andrews. St Andrews, KY16 9AL, Scotland, United Kingdom.

21 Atmospheric relative humidity (RH) is an important parameter affecting vegetation yet palaeo-

22 proxies for RH are scarce and difficult to calibrate. Here we use triple oxygen $\left(\delta^{17} \mathrm{O}\right.$ and $\left.\delta^{18} \mathrm{O}\right)$

23 and hydrogen $(\delta \mathrm{D})$ isotopes of structurally bounded gypsum hydration water (GHW) extracted

24 from lacustrine gypsum to quantify past changes in paleo-atmospheric RH. An evaporation 
25 isotope mass balance model is used together with Monte Carlo simulations to determine the

26 range of climatological conditions that simultaneously satisfy the stable isotope results of GHW,

27 and with statistically robust estimates of uncertainty. We apply this method to reconstruct the

28 isotopic composition of paleo-waters of Lake Estanya (NE Spain) and changes in atmospheric

$29 \mathrm{RH}$ over the last glacial termination and Holocene (from $\sim 15$ to 0.6 cal. kyrs BP). The isotopic

30 record indicates the driest conditions occurred during the Younger Dryas (YD; 12-13 cal. kyrs

31 BP). We estimate a RH of $\sim 40-45 \%$ during the YD, which is $\sim 30-35 \%$ lower than today.

32 Because of the southward displacement of the Polar Front to $\sim 42^{\circ} \mathrm{N}$, it was both windier and

33 drier during the YD than the Bølling-Allerød period and Holocene. Mean atmospheric moisture

34 gradually increased from the Preboreal to Early Holocene ( 11 to 8 cal. kyrs BP, 50-60\%),

35 reaching 70-75\% $\mathrm{RH}$ from $\sim 7.5$ cal. kyrs BP until present-day. We demonstrate that combining

36 hydrogen and triple oxygen isotopes in GHW provides a powerful tool for quantitative estimates

37 of past changes in relative humidity.

39 Keywords: triple oxygen isotopes, gypsum hydration water, relative humidity, lake sediments,

40 Younger Dryas, Late Glacial-Holocene transition.

\section{1. Introduction}

43 The presence of gypsum $\left(\mathrm{CaSO}_{4} \cdot 2 \mathrm{H}_{2} \mathrm{O}\right)$ in lacustrine sediments is commonly interpreted as

44 evidence of dry climatic conditions in the past (Hodell et al., 1995, 2005; 2012; Torfstein et al.,

45 2008; Morellón et al., 2009a; Escobar et al., 2012, amongst many others). Evaporation of $\mathrm{Ca}^{2+}-$

$46 \mathrm{SO}_{4}{ }^{2-}$-rich lake waters can lead to gypsum supersaturation under conditions of high evaporation

47 relative to precipitation (inflow). These conditions are generally accompanied by decreased input 
48 of fine-grained allochthonous sediments as a result of decreasing runoff, resulting in sediments

49 that are dominantly composed of gypsum. Interbedded layers of gypsum and other "non-

50 evaporitic" facies in lakes are often attributed to alternating wet and dry conditions (e.g. Hodell

51 et al., 1995; Ortiz et al., 2006; Morellón et al., 2009a; Escobar et al., 2012; Valero-Garcés et al.,

52 2014; Li et al., 2017).

53 The isotopic composition of lake waters is sensitive to long-term changes in the

54 Evaporation/Inflow (E/I) regime and atmospheric relative humidity (RH), among other

55 parameters (Gibson et al., 2016). In addition to $\mathrm{E} / \mathrm{I}$ and $\mathrm{RH}$, climatic variations recorded in

56 lacustrine carbonates (i.e. $\delta^{18} \mathrm{O}$ of authigenic carbonates) can be masked by the effect of

57 temperature on the oxygen isotopic value during carbonate precipitation (Hodell et al., 2012). In

58 contrast, structurally bounded gypsum hydration water (GHW) can be used to reconstruct the

59 isotopic value of paleo-lake waters with little to no effect of temperature. The fractionation

60 factors for oxygen and hydrogen isotopes between the free solution and GHW are largely

61 independent of temperature in the range of most lakes (e.g. $10-35^{\circ} \mathrm{C}$; Gázquez et al., 2017a).

62 Thus, the oxygen and hydrogen isotopes $\left(\delta^{18} \mathrm{O}\right.$ and $\left.\delta \mathrm{D}\right)$ of GHW can be used to infer the isotopic

63 composition of paleo-lake waters at the time of gypsum precipitation (Hodell et al., 2012; Grauel

64 et al., 2016; Li et al., 2017). GHW retains the isotopic values of the parent solution provided that

65 it has not been altered by post-depositional processes (e.g. exposure to temperature $>50^{\circ} \mathrm{C}$ after

66 deposition, solution-reprecipitation, etc.). Whether the original isotopic composition of GHW has

67 been preserved or not must be evaluated on a case-by-case basis (Hodell et al., 2012; Evans et

68 al., 2015; Gázquez et al., 2017a).

69 Recent analytical developments permit precise measurements of triple oxygen isotopes

$70\left({ }^{17} \mathrm{O} /{ }^{18} \mathrm{O} /{ }^{16} \mathrm{O}\right.$ ), and the derived parameter ${ }^{17} \mathrm{O}$-excess (also called $\Delta{ }^{17} \mathrm{O}$ ), in natural waters (Luz 
71 and Barkan, 2010; Steig et al., 2014) and GHW (Gázquez et al., 2015) with precision better than

$72 \pm 0.01 \%$ (i.e. 10 per meg; $\pm 1 \sigma$ ). This parameter is defined as:

$$
{ }^{17} \mathrm{O} \text {-excess }=\ln \left(\delta^{17} \mathrm{O}+1\right)-0.528 \ln \left(\delta^{18} \mathrm{O}+1\right)(\text { Eq. } 1)
$$

74 where:

$75 \quad \delta^{17} \mathrm{O}$ and $\delta^{18} \mathrm{O}$ denote the ${ }^{17} \mathrm{O} /{ }^{16} \mathrm{O}$ and ${ }^{18} \mathrm{O} /{ }^{16} \mathrm{O}$ in water standardized to V-SMOW (Barkan and 76 Luz, 2005; Luz and Barkan, 2010; Schoenemann et al., 2013). The value of 0.528 has been 77 proposed to describe the $\delta^{17} \mathrm{O}$ and $\delta^{18} \mathrm{O}$ relationship in rainwater worldwide (Luz and Barkan, 78 2010). The ${ }^{17}$ O-excess averages $\sim 37$ per meg in modern meteoric waters and shows lower values 79 in evaporated water (Barkan and Luz, 2010; Steig et al., 2014; Surma et al., 2015). The trajectory 80 of $\delta^{18} \mathrm{O}$ and ${ }^{17} \mathrm{O}$-excess in evaporated water is relatively insensitive to temperature and salinities 81 below $100 \mathrm{~g} / \mathrm{l}$ (Barkan and Luz, 2010; Passey et al., 2014); however, it is significantly affected 82 by other parameters such as the hydrological balance of the water body and atmospheric RH 83 (Surma et al., 2015; Gázquez et al., 2017b; Herwartz et al., 2017; see Fig. 1).

84 Despite the potential of lake sediments as palaeoclimatic archives, stable isotopes in inorganic 85 and organic proxies often allow only qualitative interpretation of past hydrological changes. 86 Quantitative reconstructions from isotope proxy data, including changes in atmospheric relative 87 humidity, have been difficult to achieve and calibrate. Here we evaluate the potential of using 88 triple oxygen and hydrogen isotopes in lacustrine GHW to quantify changes in atmospheric 89 relative humidity in the past. We use a Raleigh evaporation isotope mass balance (IMB) to 90 estimate quantitatively climatic conditions at the time of gypsum precipitation. Monte Carlo 91 simulations are used to find the most probable solution to the model and evaluate uncertainties

92 for RH. We apply this method to isotopic data $\left(\delta^{17} \mathrm{O}, \delta^{18} \mathrm{O}\right.$ and $\delta \mathrm{D}$, and derived d-excess and $93{ }^{17}$ O-excess) of gypsum hydration water from Lake Estanya (Southern Pre-Pyrenees, NE Spain) 
94 to infer climate during the Late Glacial and Holocene periods (ca. 15 cal. kyrs BP to 0.6 cal. kyrs

$95 \mathrm{BP})$. We model the isotopic values of paleo-lake Estanya under different

96 environmental/geochemical scenarios. We compare the isotopic results and derived RH values

97 with previous sedimentological and geochemical proxies in the lake sequence (Morellón et al.,

98 2009b), as well as other biological indicators such as pollen, diatoms and chironomids (Morellón

99 et al., 2011; Vegas-Vilarrùbia et al., 2013; González-Sampériz, 2017). Lastly, we discuss more

100 generally the potential application of the method to other lakes.

\section{2. Approach and model}

102 The oxygen $\left(\delta^{17} \mathrm{O}\right.$ and $\left.\delta^{18} \mathrm{O}\right)$ and hydrogen $(\delta \mathrm{D})$ isotopic composition of lake waters increase

103 with more arid conditions and higher evaporation relative to inflow (E/I). Each isotope ratio

104 follows a slightly different fractionation leading to variability in d-excess and ${ }^{17} \mathrm{O}$-excess

105 parameters (Surma, 2015; Gibson et al., 2016; Herwartz et al., 2017; and references therein). The

106 isotopic evolution of water during evaporation (e.g. $\delta^{18} \mathrm{O}$ vs ${ }^{17} \mathrm{O}$-excess and $\delta^{18} \mathrm{O}$ vs d-excess)

107 depends on the isotopic composition of the initial water (inflow), temperature, relative humidity,

108 the isotopic composition of the water vapor in equilibrium with the liquid water and the ratio of

109 water loss by evaporation (E) with respect to the inflow (I), with the remainder lost as outflow.

110 The process is described by the expression (Criss, 1999):

111

$$
{ }^{*} R_{W S}=\frac{{ }^{*} \alpha_{\text {evap }}^{0} \cdot(1-h) \cdot{ }^{*} R_{W I}+{ }^{*} \alpha_{e q}^{0} \cdot h \cdot E / I \cdot R_{V}}{E / I+{ }^{*} \alpha_{\text {evap }}^{0} \cdot(1-h) \cdot(1-E / I)} \text { (Eq. 2) }
$$


114 Where $* \mathrm{R}_{\mathrm{WS}}$ is the isotopic ratio of the evaporated water. $* \alpha_{\text {evap }}^{0}$ is the effective fractionation

115 factor, calculated as a product of the equilibrium fractionation factor $\left({ }^{*} \alpha_{\text {eq }}^{0}\right)$ and the diffusive

116 fractionation factor $\left({ }^{*} \alpha_{\text {diff }}^{0}\right)$ between the liquid water and vapor. The parameter $h$ is the relative

117 humidity of air ( 0 to 1$)$. $\mathrm{R}_{\mathrm{WI}}$ is the isotopic ratio of the input prior to evaporation (i.e., the inflow

118 to the lake). $R_{v}$ is the isotopic ratio of the vapor and depends on the degree to which the

119 atmospheric water vapor $\left(\mathrm{v}_{\mathrm{eq}}\right)$ is in equilibrium with $\mathrm{R}_{\mathrm{WI}}$ (Gibson et al., 2016), where:

$$
\mathrm{R}_{\mathrm{v}}=\mathrm{R}_{\mathrm{WI}} *\left(\alpha_{\text {eq }}^{0} * \mathrm{v}_{\mathrm{eq}}\right)(\text { Eq. 3) }
$$

121 E/I represents the fraction of water loss by evaporation with respect to the inflow from the 122 system (e.g. $\mathrm{E} / \mathrm{I}=0$ means no evaporation whereas $\mathrm{E} / \mathrm{I}=1$ means all the water is lost to 123 evaporation; i.e. there is no outflow). This model assumes homogeneous isotopic composition of 124 both the liquid and vapor phases.

125 Equilibrium fractionation factors for $\delta^{18} \mathrm{O}$ and $\delta \mathrm{D}$ are well known and calculated here as a 126 function of temperature using the equations of Horita and Wesolowski (1994). $\alpha^{17} \mathrm{O}^{0}$ eq is 127 calculated as $\alpha^{17} \mathrm{O}^{0}{ }_{\text {eq }}=\alpha^{18} \mathrm{O}_{\text {eq }}^{0}{ }^{\theta}$, where $\theta$ is 0.529 (Barkan and Luz, 2005). Kinetic fractionation 128 during evaporation under natural conditions is not as strongly constrained as equilibrium 129 fractionation. Here we use a combination of natural and laboratory experiments to calculate $\alpha_{\text {diff }}^{0}$ 130 (Landais et al., 2006; Barkan and Luz, 2007, Luz et al., 2009). First, $\alpha^{18} \mathrm{O}^{0}{ }_{\text {diff }}$ varies as a function 131 wind driven turbulence (Dongmann et al., 1974; Uemura et al., 2010; Haese et al., 2013) (see 132 discussion section) and is calculated as:

$$
\alpha^{18} \mathrm{O}_{\text {diff }}^{0}=1.0283^{w} \text { (Eq. 4) }
$$

134 where $w$ varies between 0.5 (pure turbulent mixing; $\alpha^{18} \mathrm{O}^{0}{ }_{\text {diff }}=1.0141$ ) and 1.0 (pure diffusion; $\left.135 \alpha^{18} \mathrm{O}_{\text {diff }}^{0}=1.0283\right)$. 
$136 \alpha \mathrm{D}^{0}{ }_{\text {diff }}$ varies as a function of $\alpha^{18} \mathrm{O}^{0}{ }_{\text {diff }}$ and temperature $\left(\mathrm{T}\right.$, in $\left.{ }^{\circ} \mathrm{C}\right)$ based on experiments by Luz

137 et al. (2009), where:

$$
\alpha \mathrm{D}^{0}{ }_{\text {diff }}=(1.25-0.02 \mathrm{~T})\left(\alpha^{18} \mathrm{O}_{\text {diff }}^{0}-1\right)+1 \text { (Eq. 5) }
$$

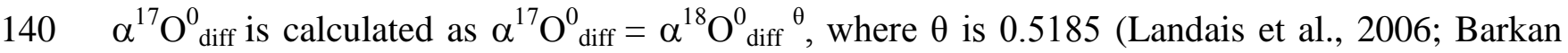
141 and Luz, 2007).

142 In $\delta^{18} \mathrm{O}-{ }^{17} \mathrm{O}$-excess and $\delta^{18} \mathrm{O}$-d-excess space (Fig. 1), the predicted trends of waters undergoing 143 evaporation in partial equilibrium with atmospheric vapor take the form of curves. We see that 144 both ${ }^{17} \mathrm{O}$-excess and d-excess are largely sensitive to $\mathrm{RH}$ during evaporation (Fig. 1A and F), 145 whereas their sensitivities to temperature are relatively small, especially for ${ }^{17} \mathrm{O}$-excess (Fig. 1B) 146 (Landais et al., 2006; Passey et al., 2014; Surma et al., 2015; Gázquez et al., 2017b; Herwartz et 147 al., 2017). Both cross-plots are moderately sensitive to turbulences (winds) on the water surface 148 during evaporation (Fig. 1C and $\mathrm{H}$ ) and to the isotopic composition of the atmospheric water 149 vapor (Fig. 1D and I). Also, both isotopic systems are very sensitive to the proportion of water 150 loss by evaporation with respect to the input (E/I) (Fig. 1E and J).

151 In summary, our isotopic model is based on three equations where $\delta^{17} \mathrm{O}, \delta^{18} \mathrm{O}$ and $\delta \mathrm{D}$ are known 152 (measured), four variables that can be constrained by modern estimates $\left(\delta^{17} \mathrm{O}, \delta^{18} \mathrm{O}\right.$ and $\delta \mathrm{D}$ of 153 the inflow and lake temperature), two poorly constrained but minor variables (turbulence and 154 vapor-precipitation equilibrium) and two significant unknowns (E/I and h). Estimating E/I and h 155 in the past requires some assumptions about the errors in the unknown variables and an 156 understanding of how these variables co-vary and introduce uncertainty in the model results (see 157 discussion section). 
159 Monte Carlo simulations performed in Matlab® is used in our method to find the possible model

160 solutions that satisfy the isotopic composition of the modern and paleo-lake water given the

161 uncertainty in both the paleo-environmental parameters considered and the analytical errors. The

162 approach is represented graphically in Figure S3. Briefly, a range of model inputs is selected

163 based on conservative estimates of their distributions in the modern and potential to change in

164 the past. The distribution of model inputs is uniform and thus produces a largely uniform set of

165 model solutions. The error in each model solution is then calculated relative to the mean and 1-

166 sigma standard deviation (1SD) of each individual data point. The normalized errors for $\delta^{18} \mathrm{O}$,

$167 \delta \mathrm{D}$, and ${ }^{17} \mathrm{O}$-excess are then combined to arrive at a total error (if no ${ }^{17} \mathrm{O}$-excess data exists it is

168 excluded from the total error). Only those model solutions that fall within the 1SD are then

169 selected. In the three-dimensional space of the $\delta^{18} \mathrm{O}, \delta \mathrm{D},{ }^{17} \mathrm{O}$-excess, this can be visualised as

170 selecting all the data points that fall within an ellipsoid with axes that extend to the 1SD

171 analytical error in each parameter. From the subset of simulations, the mean and range of model

172 inputs (e.g. relative humidity) that are constituent with the lake water isotopes can derived.

\section{3. Materials and methods}

175 Balsas de Estanya is a karstic lake complex located at the foothills of the Southern Pyrenees

$176\left(42^{\circ} 02^{\prime} \mathrm{N}, 0^{\circ} 32^{\prime} \mathrm{E}\right)$ at $670 \mathrm{~m}$ a.s.1. It is a relatively small endorheic basin of $2.45 \mathrm{~km}^{2}$ (Fig. 2) that

177 comprises multiple bodies of water. The largest and deepest lake (Estanque Grande de Abajo)

178 has been studied extensively for paleoclimate and paleolimnological reconstruction (Morellón et

179 al., 2009b; 2011; and references therein) (Fig. 2 and supplementary material). Twenty-nine

180 gypsum samples were collected from the ca. 11-m long composite sequence of Lake Estanya,

181 which is comprised of a combination of cores LEG04-1A-1K and EST06-1A-1U (Morellón et 
182 al., 2009b). The cores were recovered from the deepest areas of Estanque Grande de Abajo (Fig.

183 2). The age model is based on radiocarbon, ${ }^{137} \mathrm{Cs}$ and ${ }^{210} \mathrm{~Pb}$ and lithostratigraphy as previously

184 described by Morellón et al., (2009b) and Vegas-Vilarrùbia et al. (2013) (see supplementary

185 material).

186 GHW was extracted by heating the powdered gypsum in vacuo using a bespoke offline system

187 consisting of six vacuum lines contained within a modified gas chromatography (GC) oven in the

188 Godwin Laboratory at the University of Cambridge (UK) (Gázquez et al., 2015). Oxygen $\left(\delta^{17} \mathrm{O}\right.$

189 and $\left.\delta^{18} \mathrm{O}\right)$ and hydrogen $(\delta \mathrm{D})$ isotopes of the hydration water were measured simultaneously by

190 cavity ringdown spectroscopy (CRDS) using a L2140-i Picarro water isotope analyzer (Gázquez

191 et al., 2015 and supplementary material for details). All results are reported in parts per thousand

192 (\%) relative to V-SMOW. The uncertainty of the method was $\pm 0.05 \%$ for $\delta^{17} \mathrm{O}, \pm 0.1 \%$ for $\delta^{18} \mathrm{O}$

193 and $\pm 0.6 \%$ for $\delta \mathrm{D}, \pm 0.8 \%$ for d-excess and \pm 8 per meg for ${ }^{17} \mathrm{O}$-excess ( $1 \mathrm{SD}$ ).

194 Additionally, the hydration water of two samples were also analyzed for $\delta^{17} \mathrm{O}$ and $\delta^{18} \mathrm{O}$ using a 195 modified version of the fluorination-IRMS method of Barkan and Luz (2005) at the Institute for 196 Geology and Mineralogy at the University of Cologne, Germany (Surma et al., 2015; Gázquez et 197 al., 2015; Herwartz et al., 2017). Rain (n=59) and lake waters ( $\mathrm{n}=61)$ collected between 2001 and 1982012 were analyzed for oxygen and hydrogen stable isotopes (Tables S2, S3, S4 and S5 in 199 supplementary material).

\section{4. Results}

201 Twenty-nine gypsum samples, ranging in age from 14.7 to 0.6 cal. kyrs BP, were analyzed for

202 stable isotopes in GHW. The $\delta^{17} \mathrm{O}$ varies from $3.8 \%$ to $7.1 \%$, $\delta^{18} \mathrm{O}$ from $6.3 \%$ to $14.9 \%$ and $\delta \mathrm{D}$ 203 from $-26.1 \%$ to $3.0 \%$ (Table S1 and Fig. S2 in supplementary material). The lowest values 
204 correspond to gypsum samples at $136 \mathrm{~cm}$ below lake floor; ca. $620 \mathrm{cal}$. yr BP) and the highest 205 values to gypsum at $588 \mathrm{~cm}$ depth; 12 cal. kyrs BP).

206 The oxygen and hydrogen isotope composition of the parent water from which the gypsum 207 formed is calculated from GHW using recently revised fractionation factors ( $\alpha_{\text {gypsum-water }}$ ) 208 (Gázquez et al., 2017a) that are more precise and accurate than previous values (Gonfiantini and 209 Fontes, 1963; Fontes and Gonfiantini, 1967; Hodell et al., 2012). We use $\alpha^{18} \mathrm{O}_{\text {gypsum-water }}$ of 2101.00355 and $\alpha \mathrm{D}_{\text {gypsum-water }}$ of 0.979 corresponding to a temperature of $15^{\circ} \mathrm{C}$, representing roughly

211 the modern mean temperature of the lake water $\left(\sim 12.5^{\circ} \mathrm{C}\right)$. Note that both, $\alpha^{18} \mathrm{O}_{\text {gypsum-water }}$ and $212 \alpha \mathrm{D}_{\text {gypsum-water }}$ are largely unaffected by temperature in the range from $10^{\circ} \mathrm{C}$ to $35^{\circ} \mathrm{C}$ (Gázquez et 213 al., 2017a). The use of temperatures that are $10^{\circ} \mathrm{C}$ higher or lower changes the $\delta^{18} \mathrm{O}$ values by 214 only $\sim \pm 0.1 \%$ and $\delta \mathrm{D}$ by $\sim \pm 2 \%$, which is not very significant relative to the analytical precision 215 of our method.

216 The relation between $\alpha^{17} \mathrm{O}_{\text {gypsum-water }}$ and $\alpha^{18} \mathrm{O}_{\text {gypsum-water }}$ is given by the parameter $\theta\left(\alpha^{17} \mathrm{O}_{\text {gypsum- }}\right.$ 217 water $=\alpha^{18} \mathrm{O}_{\text {gypsum-water }}{ }^{\theta}$, which has been found to be $0.5297 \pm 0.0012$ and does not depend on 218 temperature between 3 and $55^{\circ} \mathrm{C}$ (Gázquez et al., 2017a). Therefore, we use $\alpha^{17} \mathrm{O}_{\text {gypsum-water }}$ of 219 1.00188. Using these alpha values, we found that the paleo-lake water (i.e., GHW corrected for 220 fractionation) plot on an evaporation line with slope of 3.4 (Fig. 3). This evaporation line is 221 comprised of paleo-lake waters from different ages that evaporated under different 222 environmental conditions. Therefore, the slope of this line does not convey a unique paleo223 hydrological significance.

224 From 14.7 to 13.3 cal. kyrs BP during the Bølling-Allerød (B-A) period, the $\delta^{18} \mathrm{O}$ values of the 225 lake water increased gradually from $7.8 \%$ at 14.7 cal. kyrs BP to $10.6 \%$ at 13.3 cal. kyrs BP, 226 while $\delta \mathrm{D}$ increased from $12.1 \%$ o to $21.9 \%$. During the same period, d-excess varied from - 
$22750.4 \%$ to $-62.6 \%$. The $\delta^{18} \mathrm{O}$ and $\delta \mathrm{D}$ of the lake water shows the highest values of the entire 228 record at ca. 12 cal. kyrs BP (11.3\%o and 23.7\%o, respectively) during the Younger Dryas (YD)

229 Chronozone. This time also marked the lowest d-excess values (-69\%) (Table S1). During the 230 following Preboreal-Holocene period (from 11.7 to 7.5 cal. kyrs BP), $\delta^{18} \mathrm{O}$ and $\delta \mathrm{D}$ values 231 decreased to $\sim 5.5 \%$ and $\sim 2.4 \%$, respectively. Finally, the isotopic composition of the lake water 232 reached full Holocene conditions after $\sim 7.5$ cal. kyrs BP $\left(\delta^{18} \mathrm{O}\right.$ of $4.3 \pm 0.7 \%$ and $\delta \mathrm{D}$ of $2331.5 \pm 2.9 \%$ ), showing similar values to modern Lake Estanya water $\left(\delta^{18} \mathrm{O}\right.$ of $3.6 \pm 0.7 \% 0$ and $\delta \mathrm{D}$ of $234-2.4 \pm 7.1 \% 0$ ). The ${ }^{17} \mathrm{O}$-excess of paleolake water during the Holocene ranged from -63 to -46 per 235 meg, also resembling modern values (-51 per meg). More negative ${ }^{17} \mathrm{O}$-excess values were 236 recorded during the Preboreal-Early Holocene (-103 to -94 per meg), the YD (-82 per meg) and 237 the B-A period (-67 per meg).

239 5. Discussion

\section{$240 \quad$ 5.1. Reliability of GHW results}

241 Recent stable isotope studies of GHW in lakes have produced relevant paleoclimatic records that 242 closely agree with other local and regional climatic proxies (Hodell et al., 2012; Grauel et al., 243 2016; Li et al., 2017 and the present study). Such excellent correlations undoubtedly indicate 244 that, at least in some cases, the primary isotopic composition of GHW is preserved in time. 245 Investigations on Messinian gypsum deposits (ca. 5.9 Ma) also suggest no isotopic exchange or 246 alteration of the primary isotopic signal (Evans et al. 2015). However, it must be considered that

247 in other sedimentary sequence, GHW may have undergone isotopic modification, for example by 248 dehydration/rehydration cycles as a result exposure of gypsum to temperature $>50^{\circ} \mathrm{C}$ (e.g. burial 
249 and exhumation cycles). Therefore, the reliability of stable isotopes in GHW to reconstruct the

250 isotopic composition of paleo-waters should be evaluated on a case-by-case basis.

251 There are several lines of evidence that GHW in Lake Estanya preserves its primary isotopic 252 signature. After applying fractionation factors, the values of the Mid- Late-Holocene paleolake 253 waters roughly match the modern lake water; however, the Early Holocene and Late Glacial 254 paleolake waters ( 7.5 to $\sim 15$ cal. kyrs BP) show considerably more enriched values. If the 255 GHW had exchanged with sediment pore water, we would expect a relatively homogeneous 256 isotopic profile with values similar to the current lake water. Because the burial depth is shallow 257 and sediments are porous we expect any isotopic gradients in pore water to be strongly 258 attenuated by diffusion and advection with overlying lake water.

259 The isotopic changes in GHW through the late Glacial-Holocene transition and the Holocene 260 strongly correlate with major climatic changes recorded by other regional and local paleoclimate 261 archives, including several sedimentary proxies in Lake Estanya. Accordingly, we suggest the 262 hydration water of gypsum deposits in Lake Estanya reflects the isotopic composition of the 263 paleo-lake water during the latter part of the last deglaciation and Holocene.

\section{5.2. Determining RH from isotopic analysis of GHW}

266 The ability of GHW to record the isotopic composition of the original fluid, with little to no 267 effect of temperature, makes it a near direct proxy for the isotopic composition of paleowater.

268 The method presented here permits $\delta^{17} \mathrm{O}, \delta^{18} \mathrm{O}$ and $\delta \mathrm{D}$, and derived d-excess and ${ }^{17} \mathrm{O}$-excess to 269 be determined simultaneously in the same sample. The isotopic composition of paleo-lake water 270 can then be used to model the hydrologic parameters of the basin and climatic conditions at the

271 time of gypsum precipitation. Importantly, the ability of this method to reconstruct the ${ }^{17} \mathrm{O}$ - 
272 excess of paleo-waters, which is dependent of $\mathrm{RH}$ and practically insensitive to temperature

273 during water evaporation, constitutes a powerful tool for paleo-hydrologic reconstructions.

274 When modelling the isotopic composition of paleo-lakes to fit the GHW data, several parameters

275 must be known or assumed. The uncertainty in some variables, including temperature and the

276 isotopic composition of the freshwater member, have relatively little effect on the results of the

277 model (Fig. 4 and 5B). For example, a temperature change of $3-5^{\circ} \mathrm{C}$, as expected for the last

278 Glacial-Holocene transition in some regions (see section 5.3), barely affects the model results for

$279{ }^{17} \mathrm{O}$-excess (up to $\sim \pm 2$ per meg in a terminal lake), whereas d-excess changes by up to $\sim 3 \%$ in a

280 terminal lake, when keeping all other parameters constant. Importantly, the model solution must

281 satisfy both ${ }^{17} \mathrm{O}$-excess and d-excess of the same paleo-water.

282 The isotopic composition of rainfall varied between glacial and interglacial periods in most

283 regions, as recorded by speleothems, paleo-groundwaters and ice cores. For example, $\delta^{18} \mathrm{O}$ of

284 freshwater in the western-Mediterranean region increased up to $\sim 1 \%$, although practically no

285 change has been observed in south Iberia during the last glacial-Holocene transition (Jasechko et

286 al., 2015) (see section 4.2. in supplementary material). As seen in Fig. 5B, when keeping other

287 parameter constant, a $1 \%$ change in $\delta^{18} \mathrm{O}$ of the input will result in uncertainties of 3 to $4.6 \%$ in

288 the modeled RH. However, it worth noting that larger change in $\delta^{18} \mathrm{O}$ of the rainfall may be

289 expected in other regions; for example, in areas affected by monsoonal systems and large

290 variations in the "amount effect" over glacial-interglacial cycles (e.g. southern Asia; Kathayat et

291 al., 2016). Therefore, uncertainties in the isotopic composition of the freshwater member must be

292 considered as a potential source of error for quantitative paleo-humidity estimates when using

293 this method. 
294 The isotopic composition of the modern atmospheric vapor and how it varies with time is 295 unknown in most regions, nor there are estimates available for this parameter in the past. 296 However, a recent study suggests that the isotopic composition of atmospheric vapor is often in 297 partial equilibrium with that of local freshwater. A degree of equilibrium of $75 \%$ seems 298 reasonable for most tropical and intertropical regions (Gibson et al., 2016). Our IMB model does 299 not reproduce the measured $\delta^{18} \mathrm{O}, \delta^{17} \mathrm{O}$ and $\delta \mathrm{D}$ ratios for any reasonable set of input parameters 300 when full equilibrium is assumed. The model is relatively sensitive to the isotopic composition 301 of the vapor, as shown in Fig 1D. This must be considered when modeling the isotopic 302 composition of lakes in coastal areas that can be affected by advection of marine air masses, 303 whose isotopic composition is in equilibrium with seawater instead of freshwater.

304 The effect of turbulence (e.g., wind) on the isotopic equilibrium between water and vapor is 305 accounted for in our model by replacing $* \alpha_{\text {diff }}$ by $\left(* \alpha_{\text {diff }}\right)^{\mathrm{w}}$, where the exponent ' $w$ ' is set between 3060.5 (pure turbulence) and 1 (no wind) (Dongmann et al., 1974; Uemura et al., 2010; Haese et al., 307 2013). The relationship between this parameter and the wind speed is not well constrained; 308 however, it is known that the proportion of $* \alpha_{\text {diff }}$ may be suppressed by turbulent flow induced 309 by wind (e.g. Horita et al. 2008). As exemplified in Fig. 4 (see section 5.3 and supplementary 310 material for details), when turbulence is not considered, the model yields d-excess and ${ }^{17} \mathrm{O}$ 311 excess values that are systematically too low compared to the analytical data for some periods 312 (i.e. Younger Dryas; $12 \mathrm{ka}$ ). This offset can be corrected by reducing the value of the exponent 313 ' $\mathrm{w}$ ' for periods that are documented to have been windier than the average.

314 The hydrologic balance of the lake (E/I) controls the isotopic composition of the water. Lakes 315 with high E/I values (i.e. lakes of dry regions) may also show high salinities due to accumulation 316 of salts in the basin. However, the salt effect on the IMB becomes significant only at $>100 \mathrm{~g} / \mathrm{l}$ 
317 (Sofer and Gat, 1972; Criss 1999; Herwartz et al., 2017). This salinity values may be reached in

318 some hypersaline chlorine-rich lakes, for which a salinity correction would be needed (Herwartz

319 et al., 2017). Nevertheless, gypsum precipitation does not necessary occur in high-salinity 320 environments, but often takes place in freshwater lakes saturated in calcium sulfate with 321 relatively low salinities, often $\sim 3-4$ g/l (e.g. Hodell et al., 2005; Perez-Bielsa, 2013). The E/I of 322 the lake has a large impact on the IMB. The E/I in modern lakes can be asserted by a simple 323 mass balance of conservative elements in water (e.g. sodium chloride), but this parameter in the 324 past is generally unknown. Figure $5 \mathrm{~A}$ shows that when E/I exceeds 0.75 , changes in this 325 parameter barely affect the RH values derived from the model. We estimate the errors for the RH 326 to be smaller than 5\% (1SD) when the lake approached terminal conditions, as required for 327 saturation in gypsum of water. In contrast, when the model is forced to E/I $<0.5$ the scatter of $R H$ 328 values increases (ca. $\pm 15 \%, 1 \mathrm{SD}$ ), suggesting that the resolution of our method for $\mathrm{RH}$ 329 estimation is better for lake systems close to closed conditions (all the water loss by evaporation 330 and practically not outflow) than for throughflow lakes. This is because of the $\delta^{18} \mathrm{O}-{ }^{17} \mathrm{O}$-excess 331 and $\delta^{18} \mathrm{O}$-d-excess trajectories of evaporated waters under different $\mathrm{RH}$ diverge considerably 332 when E/I approaches 1 (Fig. 1). In contrast, the isotopic trajectory of water in a throughflow lake 333 (e.g. E/I<0.5) barely differs when evaporation occurs under different conditions of RH. This 334 indicates the method described here is especially suitable for lakes in which gypsum formed 335 under arid or semiarid conditions (Surma et al., 2015).

336 In summary, when the model is forced to match both the ${ }^{17} \mathrm{O}$-excess and d-excess of the paleo337 water measured in GHW and model inputs are selected based on conservative estimates and 338 appropriate errors, the derived uncertainty in $\mathrm{RH}$ can be as low as $\pm 3 \%(1 \sigma)$. The model is 339 insensitive to temperature changes, whereas uncertainties in the isotopic composition of the 
340 rainfall can have a significant effect, especially in regions where the isotopic composition of

341 rainfall is highly variable. The accuracy of the method is best when applied to lakes under

342 arid/semiarid climate ( $\mathrm{RH}<70 \%)$ and elevated E/I (hydrologically closed basins). Most of these

343 conditions are met for Lake Estanya where we have applied the method to estimate RH changes

344 during the last glacial termination and Holocene.

\section{5.3. Application to Lake Estanya}

347 We applied the approach described above to reconstruct paleoclimate at Lake Estanya in the

348 Southern Pyrenees during the late Glacial-Holocene transition and the Holocene. We interpret 349 past changes in the isotopic composition in GHW of Lake Estanya in terms of changing RH (see 350 supplementary material for detailed rationale about the environmental parameters selected for the 351 model).

\section{$353 \quad$ 5.3.1. Bølling-Allerød period}

354 Between $\sim 15$ and $\sim 13$ cal. kyrs BP, coinciding with the Bølling-Allerød (B-A) period, the lake

355 showed intermediate $\delta^{18} \mathrm{O}$ and $\delta \mathrm{D}$ values compared with the later stages. This indicates a more 356 positive water balance compared to the subsequent period (i.e. 12.8-11.6 cal. kyrs BP; Younger 357 Dryas). Our model based on ${ }^{17} \mathrm{O}$-excess and d-excess suggests that $\mathrm{RH}$ during the B-A period 358 was $\sim 55-65 \%$. This is $\sim 10-15 \%$ less than modern conditions in the Estanya region $(\sim 70-75 \%)$.

359 This finding is consistent with comparatively lower water salinity and greater productivity in the 360 paleo-lake than during the YD, inferred from the elemental composition (XRF) of the sediments 361 and $\delta^{13} \mathrm{C}$ of organic matter, respectively (Morellón et al., 2009b) (Fig. 6). During the B-A period, 
362 a trend towards heavier $\delta^{18} \mathrm{O}$ and $\delta \mathrm{D}$ values was recorded, reaching a relative maximum at ca.

36313.2 cal. kyrs BP, coinciding with a cold period.

366 5.3.2. Younger Dryas

367 Relatively enriched $\delta^{18} \mathrm{O}$ and $\delta \mathrm{D}$ values (11.3\%0 and $23.7 \%$, respectively) and lower d-excess (368 69\%o) in the lake water recorded during the YD are also in good agreement with higher E/I 369 compared to previous and later stages. Accordingly, a maximum in water salinity during the YD 370 is also evidenced by the greatest contents of $\mathrm{S}$ and $\mathrm{Ca}^{2-}$ in this section of the core (XRF data in 371 Morellón et al., 2009b). The modelled ${ }^{17} \mathrm{O}$-excess and d-excess of the paleolake water during the 372 YD indicate that atmospheric RH decreased to $40-45 \%$ during the aridity peak at $\sim 12$ cal. kyrs 373 BP. This is $\sim 10-15 \%$ less than during the previous B-A period and $\sim 30-35 \%$ less compared to 374 present. These values are also consistent with recent studies of biomarkes in Lake Meerfelder 375 Maar (Germany) that suggest RH decreased by $8-15 \%$ during YD compared with the previous 376 B/A period (Rach et al. 2017). Also, these results are in good agreement with previous studies 377 suggesting the YD in NE Spain was characterized by cold and arid conditions, with particularly 378 extreme conditions in higher altitudes of the Pyrenees (González-Sampériz et al., 2006). 379 Accordingly, generally drier conditions were recorded elsewhere on the Iberian Peninsula 380 (Moreno et al., 2012). A high-resolution speleothem record from El Seso Cave (Southern 381 Pyrenees) reveals a modest cooling of $1.3^{\circ} \mathrm{C}$ compared with other circum-Iberian sea surface 382 temperature reconstructions (Cacho et al., 1999; Eynaud et al., 2009), and a significant decrease 383 in rainfall during the first part of the YD (12.9-12.5 cal krys BP) followed by a progressive 384 increase in humidity afterwards. 
385 Drier conditions throughout the YD have also been inferred from other paleoclimatic sequences

386 in Iberia (Moreno et al., 2012, Garcia-Ruiz et al., 2016; González-Sampériz et al., 2017). The

387 maximum southward migration of the polar front during the YD reached $42^{\circ} \mathrm{N}$ (Broecker et al.,

388 1988; Lane et al., 2013), approximately the latitude of the Southern Pyrenees and Lake Estanya.

389 Marine records from the Iberian Margin found a pronounced cooling during this period, even

390 more intense than in the LGM (Eynaud et al., 2009 and references therein). Furthermore, the

391 existence of loess deposits (13-10 cal. kyrs BP) in Central Spain (Bateman and Díez-Herrero,

392 2001) also supports an increase in aridity and perhaps wind speed in Western Europe during the

393 YD (Brauer et al., 2008), as suggested by our model results.

\section{5.3.3. Holocene}

396 The Early Holocene period (11.7 to 7.5 cal. kyrs BP) was characterized by a decrease in $\delta^{18} \mathrm{O}$ 397 and $\delta$ D values (by $\sim 9 \%$ and $\sim 20 \%$, respectively). This indicates a more positive water balance 398 (lower E/I) compared to the YD. Our model indicates that RH increased to 50-60\% during the 399 Early Holocene ( 7.5-11 cal. kyrs BP). Pollen-based vegetation reconstructions indicate 400 relatively dry conditions during the transition to the Holocene marked by increasing Juniper $s p$. 401 and decreasing mesophytes (González-Sampériz et al., 2017). The isotope values reveal a 402 comparatively large increase in humidity relative to the YD, which is not reconstructed by 403 sedimentary facies and palynology but is in agreement with other paleohydrological records of 404 NE Spain and other regions from the Iberian Peninsula (Moreno et al., 2012; Morellón et al, 405 2014; González-Sampériz et al. 2017).

406 The atmospheric reorganization following the YD led to a rapid resumption of the Atlantic 407 Meridional Overturning Circulation (AMOC) and a northwards return of the polar front to $50^{\circ}$ - 
$40860^{\circ} \mathrm{N}$ (Lane et al., 2013). This shifted the trajectory of the westerlies north to the Iberian

409 Peninsula, and thus weakening wind intensity and increasing humidity in Southern Europe. This

410 relative increase in moisture with respect to the previous scenario, the YD, was also reflected by

411 a decrease in the salinity of the lake water (Fig. 6) in Estanya and by an expansion of Juniper sp.

412 population in the watershed (Vegas-Vilarrubia et al., 2013; González-Sampériz et al., 2017).

413 During the remainder of the Holocene ( 7.5 to 0.6 cal. kyrs BP) the isotopic values of the lake 414 water averaged around $4.3 \pm 0.7 \%$ o for $\delta^{18} \mathrm{O}$ and $-1.5 \pm 2.9 \%$ o for $\delta \mathrm{D}$, and showed less variability 415 than the Late Glacial owing to higher water level. The Holocene paleo-lake water values 416 recorded by gypsum are in accordance with modern $\delta^{18} \mathrm{O}$ and $\delta \mathrm{D}$ of the lake water, which 417 indicates that environmental conditions were similar to present. During the Mid- Late-Holocene 418 (7.5 cal. kyrs BP to 0.6 cal. kyrs BP), atmospheric RH stabilized around $~ 70 \%$. This value is 419 similar to the modern RH measured in the Lake Estanya region (annual mean of $\sim 70-75 \%$, 420 Perez-Bielsa, 2013). These results agree with previous reconstructions based on sedimentology 421 and geochemistry, which also show rather stable conditions similar to the present with short422 lived abrupt hydrological fluctuations and an aridification trend after 4.5 to 4 cal. kyrs BP 423 (Morellón et al., 2009b).

\section{6. Conclusions}

426 We propose a new proxy for quantitative estimates of paleo-humidity. Analysis of GHW permits 427 the actual isotopic composition of paleo-waters to be determined, with little to no effect of 428 temperature. We couple triple oxygen and hydrogen isotopes in hydration water of lacustrine 429 gypsum and an Isotope Mass Balance model to quantify changes in RH in the past. Using Monte 430 Carlo simulations, the RH uncertainties derived from the input parameters to our model are 
431 estimated. This can be as low as $3 \%(1 \sigma)$ when the model is forced to match both the ${ }^{17} \mathrm{O}$-excess

432 and d-excess of the paleo-water measured in GHW.

433 We apply this method to reconstruct the isotopic composition of paleo-waters of Lake Estanya 434 (NE Spain) and changes in atmospheric RH over the Late Glacial and Holocene periods (from $435 \sim 15$ to 0.6 cal. kyrs BP). Our results indicate $\mathrm{RH}$ of $40-45 \%$ during the YD and increasing to $70-$ $43675 \%$ during the Mid-Late Holocene. This suggests that the mean $\mathrm{RH}$ in this region during the 437 past 7.5 cal. kyr BP was similar to present (RH 75\%); however, the YD was characterized by 438 much drier conditions, with atmospheric RH $\sim 30 \%$ lower than today. The southwards shift of the 439 Polar Front to ca. $42^{\circ} \mathrm{N}$ during the coldest phases of the YD increased wind intensity and was 440 responsible for the minimum RH during this period.

441 The consistency of the results obtained from Lake Estanya with other proxies analyzed in this

442 lake and other regional paleoclimate records, demonstrates the reliability of isotopes in gypsum 443 hydration water as a tool for quantitative paleohydrological reconstructions in lake sediments. 444 Improving the analytical precision of triple oxygen isotope measurements in waters and better 445 understanding of the various parameters included in the model will reduce the uncertainties in 446 estimated RH.

\section{ACKNOWLEDGMENTS}

448 This research was supported by the ERC WIHM Project (\#339694) to DAH.

\section{$450 \quad$ References}

451 Barkan, E., Luz, B., 2005. High precision measurements of ${ }^{17} \mathrm{O} /{ }^{16} \mathrm{O}$ and ${ }^{18} \mathrm{O} /{ }^{16} \mathrm{O}$ ratios in $\mathrm{H}_{2} \mathrm{O}$, 452 Rapid Commun. Mass Spectrom. 19, 3737-3742. 
Barkan, E., Luz B., 2007. Diffusivity fractionations of $\mathrm{H}_{2}{ }^{16} \mathrm{O} / \mathrm{H}_{2}{ }^{17} \mathrm{O}$ and $\mathrm{H}_{2}{ }^{16} \mathrm{O} / \mathrm{H}_{2}{ }^{18} \mathrm{O}$ in air and their implications for isotope hydrology. Rapid Commun. Mass Spectrom. 21, 2999-3005.

Bateman, M.D., Díez-Herrero, A., 2001. The timing and relation of aeolian sand deposition in central Spain to the aeolian sand record of NW Europe. Quat. Sci. Rev. 20, 779-782.

Brauer, A., Haug, G.H., Dulski, P., Sigman, D.M., Negendank, J.F.W., 2008. An abrupt wind shift in western Europe at the onset of the Younger Dryas cold period. Nature Geosci. 1, 520523.

Broecker, W.S., Andree, M., Wolfli, W., Oeschger, H., Bonani, G., Kennett, J., Peteet, D., 1988. The chronology of the last Deglaciation: Implications to the cause of the Younger Dryas Event. Paleoceanography 3, 1-19.

Cacho, I., Grimalt, J.O., Pelejero, C., Canals, M., Sierro, F.J., Flores, J.A., Shackleton, N., 1999.

Dansgaard-Oeschger and Heinrich event imprints in Alboran Sea paleotemperatures. Paleoceanography 14, 698-705.

Criss, R.E., 1999. Principles of Stable Isotope Distribution, Oxford Univ. Press, Oxford, U. K.

Dongmann, G., Nürnberg, H.W., Förstel, H., Wagener, K., 1974. On the Enrichment of $\mathrm{H}_{2}{ }^{18} \mathrm{O}$ in the Leaves of Transpiring Plants. Rad. and Environm. Biophys. 11, 41-52.

Escobar, J., Hodell, D. A., Brenner, M., Curtis, J. H., Gilli, A., Mueller, A. D., Anselmetti, F. S., Ariztegui, D., Grzesik, D.A., Pérez, L., Schwalb, A., Guilderson, T.P., 2012. A 43-ka record of paleoenvironmental change in the Central American lowlands inferred from stable isotopes of lacustrine ostracods. Quat. Sci. Rev. 37, 92-104,

Evans, N.P., Turchyn, A., Gázquez, F., Bontognali, T.R.R., Chapman, H., Hodell, D., 2015. Coupled measurements of $\delta^{18} \mathrm{O}$ and $\delta \mathrm{D}$ of hydration water and salinity of fluid inclusions in 

gypsum from the Messinian Yesares member, Sorbas Basin (SE Spain). Earth Planet. Sci. Lett. 430, 499-510.

477 Eynaud, F., de Abreu, L., Voelker, A., Schönfeld, J., Salgueiro, E., Turon, J.-L., Penaud, A., 478 Toucanne, S., Naughton, F., Sánchez-Goñi, M.F., Malaizé, B., Cacho, I., 2009. Position of the 479 Polar Front along the western Iberian margin during key cold episodes of the last 45 ka. 480 Geochem., Geophy., Geosys. 10, Q07U05.

481 Fontes, J.C., Gonfiantini, R., 1967. Fractionnement isotopique de l'hydrogène dans l'eau de 482 cristallistion du gypse. Cr. Acad. Sci. d. Nat. 265, 4-6.

483 Frigola, J., Moreno, A., Cacho, I., Canals, M., Sierro, F.J., Flores, J.A., Grimalt, J.O., 2008. 484 Evidence of abrupt changes in Western Mediterranean Deep Water circulation during the last 48550 kyr: a high-resolution marine record from the Balearic Sea. Quat. Int. 181 (1), 88-104.

486 García-Ruiz, J.M., Palacios, D., González-Sampériz, P., de Andrés, N., Moreno, A., Valero487 Garcés, B., Gómez-Villar, A., 2016. Mountain glacier evolution in the Iberian Peninsula 488 during the Younger Dryas. Quat. Sci. Rev. 138, 16-30.

489 Gázquez, F., Mather, I., Rolfe, J., Evans, N.P., Herwartz, D., Staubwasser, M. Hodell D.A., 490 2015. Simultaneous analysis of ${ }^{17} \mathrm{O} /{ }^{16} \mathrm{O},{ }^{18} \mathrm{O} /{ }^{16} \mathrm{O}$ and ${ }^{2} \mathrm{H} /{ }^{1} \mathrm{H}$ of gypsum hydration water by 491 cavity ringdown laser spectroscopy. Rapid Commun. Mass Spectrom. 21, 1997-2006.

492 Gázquez, F., Evans, N.P., David. A. Hodell 2017a. Precise and accurate isotope fractionation 493 factors $\left(\alpha^{17} \mathrm{O}, \alpha^{18} \mathrm{O}\right.$ and $\left.\alpha \mathrm{D}\right)$ for water and $\mathrm{CaSO}_{4} \cdot 2 \mathrm{H}_{2} \mathrm{O}$ (gypsum). Geochim. Cosmochim. $494 \quad$ Acta, 198, 259-270.

495 Gázquez, F., Calaforra, J.M., Evans, N.P., David. A. Hodell 2017b. Using stable isotopes $\left(\delta^{17}\right.$ O, $496 \quad \delta^{18} \mathrm{O}$ and $\left.\delta \mathrm{D}\right)$ of gypsum hydration water to ascertain the role of water condensation in the 497 formation of subaerial gypsum speleothems. Chem. Geol. 452, 34-46. 
498 Gibson, J.J., Birks, S.J., Yi, Y., 2016. Stable isotope mass balance of lakes: a contemporary

499 perspective. Quat. Sci. Rev. 131, 316-328.

500 Gonfiantini, R., Fontes, J.C., 1963. Oxygen isotopic fractionation in the water of crystallization $501 \quad$ of gypsum. Nature 200, 644-646.

502 González-Sampériz, P., Valero-Garcés, B.L., Moreno, A., Jalut, G., García-Ruiz, J.M., Martí503 Bono, C., Delgado-Huertas, A., Navas, A., Otto, T., Dedoubat, J.J., 2006. Climate variability 504 in the Spanish Pyrenees during the last 30,000 yr revealed by the El Portalet sequence. Quat. $505 \quad$ Res. 66, 38-52.

506 González-Sampériz, P., Aranbarri, J., Pérez-Sanz, A., Gil-Romera, G., Moreno, A., Leunda, M., 507 Sevilla-Callejo, M., Corella, J.P., Morellón, M., Oliva, B., Valero-Garcés, B., 2017. 508 Environmental and climate change in the southern Central Pyrenees since the Last Glacial 509 Maximum: A view from the lake records. Catena 149(3), 668-688.

510 Grauel, A.L., Hodell, D., Bernasconi, S.F., 2016. Quantitative estimates of tropical temperature 511 change in lowland Central America during the last 42 ka. Earth Planet. Sci. Lett. 438, 37-46.

512 Jasechko, S., Lechler, A., Pausata, F.S.R., Fawcett, P. J., Gleeson, T., Cendón, D. I., Galewsky, 513 J., LeGrande, A. N., Risi, C., Sharp, Z. D., Welker, J. M., Werner, M. and Yoshimura. K., 514 2015. Late-glacial to late-Holocene shifts in global precipitation $\delta^{18} \mathrm{O}$. Clim. Past $11,1375-$ $515 \quad 1393$.

516 Haese, B., Werner, M., Lohmann, G., 2013. Stable water isotopes in the coupled atmosphere517 land surface model ECHAM5-JSBACH. Geosci. Model Dev. 6, 1463-1480.

518 Herwartz, D., Surma, J., Voigt, C., Assonov, S., Staubwasser, M., 2017. Triple oxygen isotope 519 systematics of structurally bonded water in gypsum. Geochim. Cosmochim. Acta 209: 254-266. 
520 Hodell, D.A, Curtis, J.H., Brenner, M., 1995. Possible role of climate in the collapse of Classic $521 \quad$ Maya civilization. Nature 375, 391-394.

522 Hodell, D.A., Benner, M., Curtis, J.H., 2005. Terminal Classic drought in the northern Maya 523 lowlands inferred from multiple sediment cores in Lake Chichancanab (Mexico). Quat. Sci. $524 \quad$ Rev. 24, 1413-1427.

525 Hodell, D., Turchyn, A.V., Wiseman, C.J., Escobar, J., Curtis, J.H., Brenner, M., Gilli, A. 526 Mueller, A.D., Anselmetti, F., Aritzegui, D., Brown, E., 2012. Late Glacial temperature and 527 precipitation changes in the lowland Neotropics by tandem measurement of $\delta^{18} \mathrm{O}$ in biogenic 528 carbonate and gypsum hydration water. Geochim. Cosmochim. Acta 77, 352-368.

529 Kathayat, G., Cheng, H., Sinha, A., Spötl, C., R. Edwards, L., Li, H.Z., Yi, X., L., Ning, Y., Cai, 530 Y., Weiguo, L.L, Breitenbach, S.F.M., 2016. Indian monsoon variability on millennial-orbital $531 \quad$ timescales. Sci. Rep. 6, 24374.

532 Landais, A., Barkan, E., Yakir, D., Luz, B., 2006. The triple isotopic composition of oxygen in 533 leaf water. Geochim. Cosmochim. Acta 70, 4105-4115.

534 Lane, C.S., Brauer, A., Blockley, S.P.E., Dulski, P., 2013. Volcanic ash reveals time535 transgressive abrupt climate change during the Younger Dryas. Geology 41, 1251-1254.

536 Li, J., Li, M., Fang, X., Zhang, G., Zhang, W., Liu, X., 2017. Isotopic composition of gypsum 537 hydration water in deep Core SG-1, western Qaidam basin (NE Tibetan Plateau), implications 538 for paleoclimatic evolution. Global Planet Change. 155, 70-77.

539 Luz, B., Barkan E., 2010. Variations of ${ }^{17} \mathrm{O} /{ }^{16} \mathrm{O}$ and ${ }^{18} \mathrm{O} /{ }^{16} \mathrm{O}$ in meteoric waters. Geochim. $540 \quad$ Cosmochim. Acta 74, 6276-6286. 
541 Morellón, M., Valero-Garcés, B., Anselmetti, F., Ariztegui, D., Schnellmann, M., Moreno, A.,

542 Mata, P., Rico, M., Corella, J.P., 2009a. Late Quaternary deposition and facies model for

543 karstic Lake Estanya (North-eastern Spain). Sedimentology 56, 1505-1534.

544 Morellón, M., Valero-Garcés, B., Vegas-Vilarrúbia, T., González-Sampériz, P., Romero, Ó.,

545 Delgado-Huertas, A., Mata, P., Moreno, A., Rico, M., Corella, J.P., 2009b. Lateglacial and

546 Holocene palaeohydrology in the western Mediterranean region: The Lake Estanya record

547 (NE Spain). Quat. Sci. Rev. 28, 2582-2599.

548 Morellón, M., Valero-Garcés, B., González-Sampériz, P., Vegas-Vilarrúbia, T., Rubio, E.,

549 Rieradevall, M., Delgado-Huertas, A., Mata, P., Romero, Ó., Engstrom, D., López-Vicente,

550 M., Navas, A., Soto, J., 2011. Climate changes and human activities recorded in the sediments

551 of Lake Estanya (NE Spain) during the Medieval Warm Period and Little Ice Age. J.

552 Paleolimnol. 46, 423-452.

553 Morellón, M., Benito, G., Moreno, A., González-Sampériz, P., Sánchez-Moya, Y., Pérez-Sanz,

554 A., Mata, P., Aranbarri, J., Sopeña, A., Valero-Garcés, B., 2014. Hydrological response to the

555 GS-1/Holocene transition in the Iberian Peninsula: environmental leads and lags, COST

556 INTIMATE MC Final workshop, Zaragoza (Spain).

557 Moreno, A., Gonzalez-Samperiz, P., Morellón, M., Valero-Garces, B.L., Fletcher, W.J., 2012 a.

558 Northern Iberian abrupt climate change dynamics during the last glacial cycle: A view from

559 lacustrine sediments. Quat. Sci. Rev. 36, 139-153.

560 Ortiz, J.E., Torres, T., Delgado, A., Reyes, E., Llamas, J.F., Soler, V., Raya, J., 2006. Pleistocene

561 paleoenvironmental evolution at continental middle latitude inferred from carbon and oxygen

562 stable isotope analysis of ostracodes from the Guadix-Baza Basin (Granada, SE Spain).

563 Palaeogeogr. Palaeoclimatol. Palaeoecol. 240, 536-561. 
564 Passey, B.H., Hu, H, Ji, H., Montanari, S., Li, S., Henkes, G.A., Levin, N.E. 2014. Triple oxygen

565 isotopes in biogenic and sedimentary carbonates. Geochim. Cosmochim. Acta 141,1-25.

566 Perez-Bielsa, C. 2013. Funcionamiento hidrogeológico de un humedal hipogenioco de origen

567 kárstico en las sierras marginas pirenaicas: Las lagunas de Estaña (Huesca). PhD Thesis.

$568 \quad$ Madrid, 419 pp.

569 Rach, O., Kahmen, A., Brauer, A., Sachse, D. 2017. A dual-biomarker appoach for 570 quantification of changes in relative humidity from sedimentary lipid D/H ratios. Clim. Past $571 \quad$ Discuss. doi:10.5194/cp-2017-7.

572 Rasmussen, S.O., Seierstad, I.K., Andersen, K.K., Bigler, M., Dahl-Jensen, D., Johnsen, S.J., 573 2008. Synchronization of the NGRIP, GRIP, and GISP2 ice cores across MIS 2 and 574 palaeoclimatic implications. Quat. Sci. Rev., 27, 18-28.

575 Schoenemann, S.W., Schauer, A. J., Steig E. J. 2013. Measurement of SLAP and GISP $\delta^{17} \mathrm{O}$ and 576 proposed VSMOW-SLAP normalization for ${ }^{17} \mathrm{O}$-excess. Rapid Commun. Mass Spec. 27, $577 \quad 582-590$.

578 Sofer Z.,Gat J.R., 1975. The lsotopic composition of evaporating brines: effect of the isotopic 579 activity ratio in saline solutions. Earth Planet. Sci. Lett. 26, 179-186.

580 Steig, E.J., Gkinis, V., Schauer, A.J., Schoenemann, S.W., Samek, K., Hoffnagle, J., Dennis, 581 K.J., Tan, S.M., 2014. Calibrated high-precision ${ }^{17} \mathrm{O}$-excess measurements using laser-current 582 tuned cavity ring-down spectroscopy, Atmos. Meas. Tech. 7, 2421-2435.

583 Surma, J., Assonov, S., Bolourchi, M.J., Staubwasser, M., 2015. Triple oxygen isotope 584 signatures in evaporated water bodies from the Sistan Oasis, Iran. Geophys. Res. Lett., 42, $585 \quad 8456-8462$. 
Torfstein, A., Gavrieli, I., Katz, A., Kolodny, Y., Stein, M., 2008. Gypsum as a monitor of the paleo-

587 limnological-hydrological conditions in Lake Lisan and the Dead Sea. Geochim. Cosmochim., 72, $588 \quad 2491-2509$.

589 Uemera, R., Barkan, E., Abe, O., Luz, B., 2010. Triple isotope composition of oxygen in 590 atmospheric water vapor. Geophys. Res. Lett. 37, L04402, doi:10.1029/2009GL041960.

591 Valero-Garcés, B., Morellón, M., Moreno, A., Corella, J.P., Martín-Puertas, C., Barreiro, F., 592 Pérez, A., Giralt, S., Mata-Campo, M.P., 2014. Lacustrine carbonates of Iberian Karst Lakes:

593 Sources, processes and depositional environments. Sedim. Geol. 299, 1-29.

594 Vegas-Vilarrúbia, T., González-Sampériz, P., Morellón, M., Gil-Romera, G., Pérez-Sanz, A., 595 Valero-Garcés, B., 2013. Diatom and vegetation responses to Late Glacial and Early 596 Holocene climate changes at Lake Estanya (Southern Pyrenees, NE Spain). Palaeogeogr., 597 Palaeoclimatol, Palaeoecol. 392, 335-349.

\section{FIGURE CAPTIONS}

600 Figure 1. Sensitivity of $\delta^{18} \mathrm{O}-{ }^{17} \mathrm{O}$-excess and $\delta^{18} \mathrm{O}$-d-excess to different environmental 601 parameters during evaporation of a water body $\left(\delta^{18} \mathrm{O}=-8 \% 0, \delta \mathrm{D}=-54 \%\right.$, ${ }^{17} \mathrm{O}$-excess $=30$ per meg 602 and d-excess $=10 \%$ ) in partial equilibrium with atmospheric vapor. The isotopic composition of 603 a terminal lake has been model under different conditions of relative humidity (A and F), 604 temperature $(\mathrm{B}$ and $\mathrm{G})$, wind $(\mathrm{C}$ and $\mathrm{H}$ ) and degree of equilibrium between the atmospheric 605 vapor and the freshwater member (D and I). The isotopic compositions of water pools with 606 different ratios of Evaporation/Inflow (E/I), keeping the rest of parameter constant, are also 607 represented $(\mathrm{E}$ and $\mathrm{J})$. 
609 Fig. 2. A. Location of Lake Estanya. The red dashed line indicates the limits of the surface

610 catchment. Coring sites in Estanque Pequeño de Abajo are labelled.

611 Fig. 3. $\delta^{18} \mathrm{O}$ and $\delta \mathrm{D}$ of rain and spring waters (green triangles), modern water from Lake Estanya

612 (red diamonds), and gypsum hydration waters (unfilled blue circles) ranging in age from 14.7 to

6130.6 cal. kyrs BP. The isotopic values of paleo-lake waters (filled blue circles) were inferred using

614 isotopic fractionation factors between gypsum hydration water and the free solution (Gázquez et

615 al., 2017a).

616

617 Fig. 4. Results of the IMB model experiments (A. $\delta^{18} \mathrm{O}$ vs. ${ }^{17} \mathrm{O}$-excess; B. $\delta^{18} \mathrm{O}$ vs. d-excess).

618 The colored diamonds represent the isotopic composition of Lake Estanya during the Holocene 619 (yellow), Preboreal (green), Younger Dryas (blue) and the Bølling-Allerød (pink) periods. The 620 model (blue lines and black dots) is tuned to fit the gypsum mother water compositions.

621 Environmental conditions for the different periods were simulated using the input parameters in 622 Table 1. The grey ellipses represent the uncertainty in the model derived from the tolerance 623 given for each input parameter.

625 Fig 5. Sensitivity experiments of the derived relative humidity to other major variables:

626 Evaporation/Input and the isotopic composition of the input. In both experiments data points 627 representative of the late-Holocene (blue markers) and the Younger Dryas (red markers) are used 628 to illustrate the potential biases in the derived relative humidity estimates: A. The derived 629 relative humidity shows a strong positive correlation to the assumed E/I in the range of $0.4-0.7$ 630 and the effect is greater at lower relative humidities (e.g. the YD). The effect is much weaker at 631 higher E/I in closed lake basins, such as Lake Estanya (as well as most other systems in which 
632 evaporite mineral precipitation occurs); B. The derived relatively humidity with respect to the

633 assumed isotopic composition of the freshwater input. Here, relatively humidity shows a small

634 positive relationship with the isotopic composition of the freshwater input, which translates into

635 an error of between $3-4.6 \%$ in relative humidity for every $1 \%$ change in the freshwater water

636 input.

637

638 Fig. 6 Isotopic composition of Lake Estanya water, reconstructed atmospheric RH during the

639 Late Glacial-Holocene transition and the Holocene and comparison with other global and

640 regional paleoclimatic archives, including, from top to bottom: 1) NGRIP $\delta^{18} \mathrm{O}$ (Rasmussen et

641 al., 2008), 2) winter (blue line) and summer (red line) insolation at $42^{\circ} \mathrm{N}, 3$ ) $\mathrm{Si} / \mathrm{Al}$ record in

642 marine core MD99-2343, offshore Minorca (Frigola et al, 2008); 4) Alboran Sea core MD95-

6432043 Sea Surface Temperature (SST) (Cacho et al., 1999); the isotopic composition of the paleo-

644 lake water reconstructed from gypsum hydration water (panels 5, 6 and 7); 8) atmospheric RH

645 obtained from our ${ }^{17} \mathrm{O}$-excess/d-excess model. The mean $\mathrm{RH}$ obtained from the ${ }^{17} \mathrm{O}$-excess

646 model are represented as diamonds (see Fig. 4A). The RH results of the Monte Carlo simulation

647 in two scenarios are represented by the color shading. Scenario 1 (blue banding) in which all the

648 model parameters are held constant for all time periods and scenario 2 (orange banding) in which

649 the model parameters are modified in the Younger Dryas as described in the main text and

650 shown in Table 1. Previous palaeoenvironmental reconstruction of Lake Estanya based on

651 sedimentological and geochemical proxies, including 9) $\delta^{13} \mathrm{C}$ in organic matter, 10) a paleo-

652 salinity proxy obtained from XRF analyses of the sedimentary sequence and, 11) relative lake

653 level reconstruction (0-10 stages) based on sedimentary facies (Morellón et al., 2009b). 
Figure 1

Click here to download high resolution image
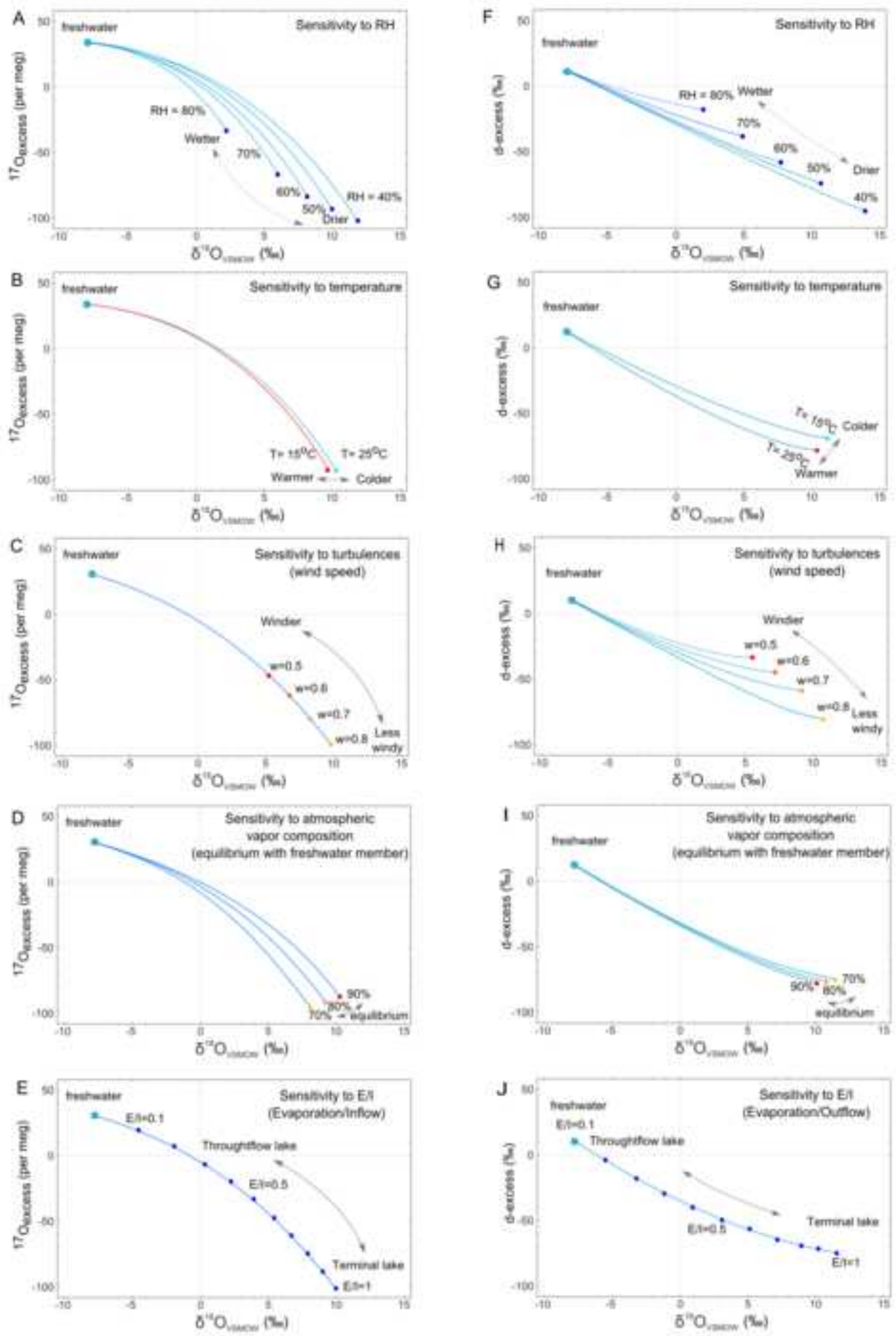


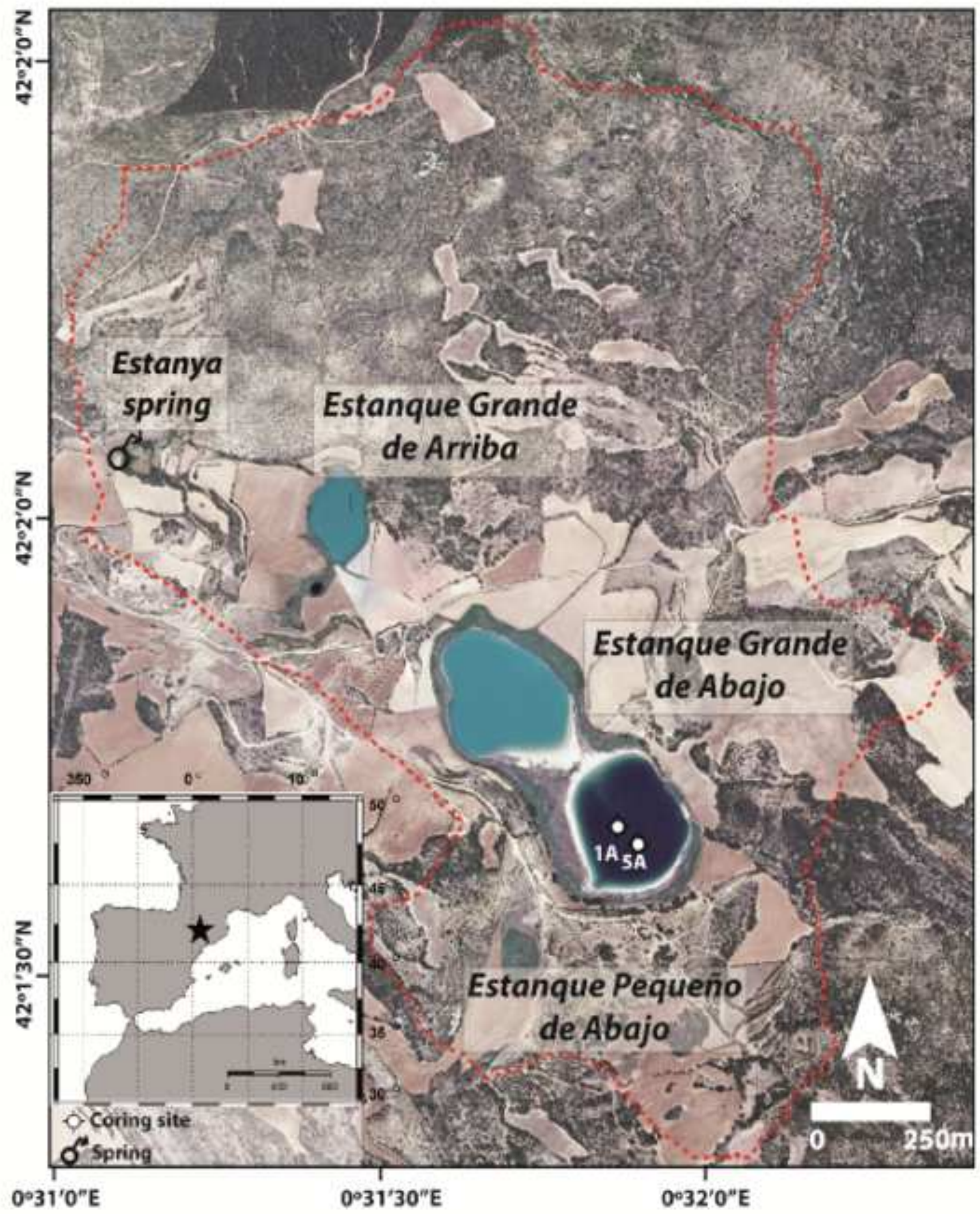




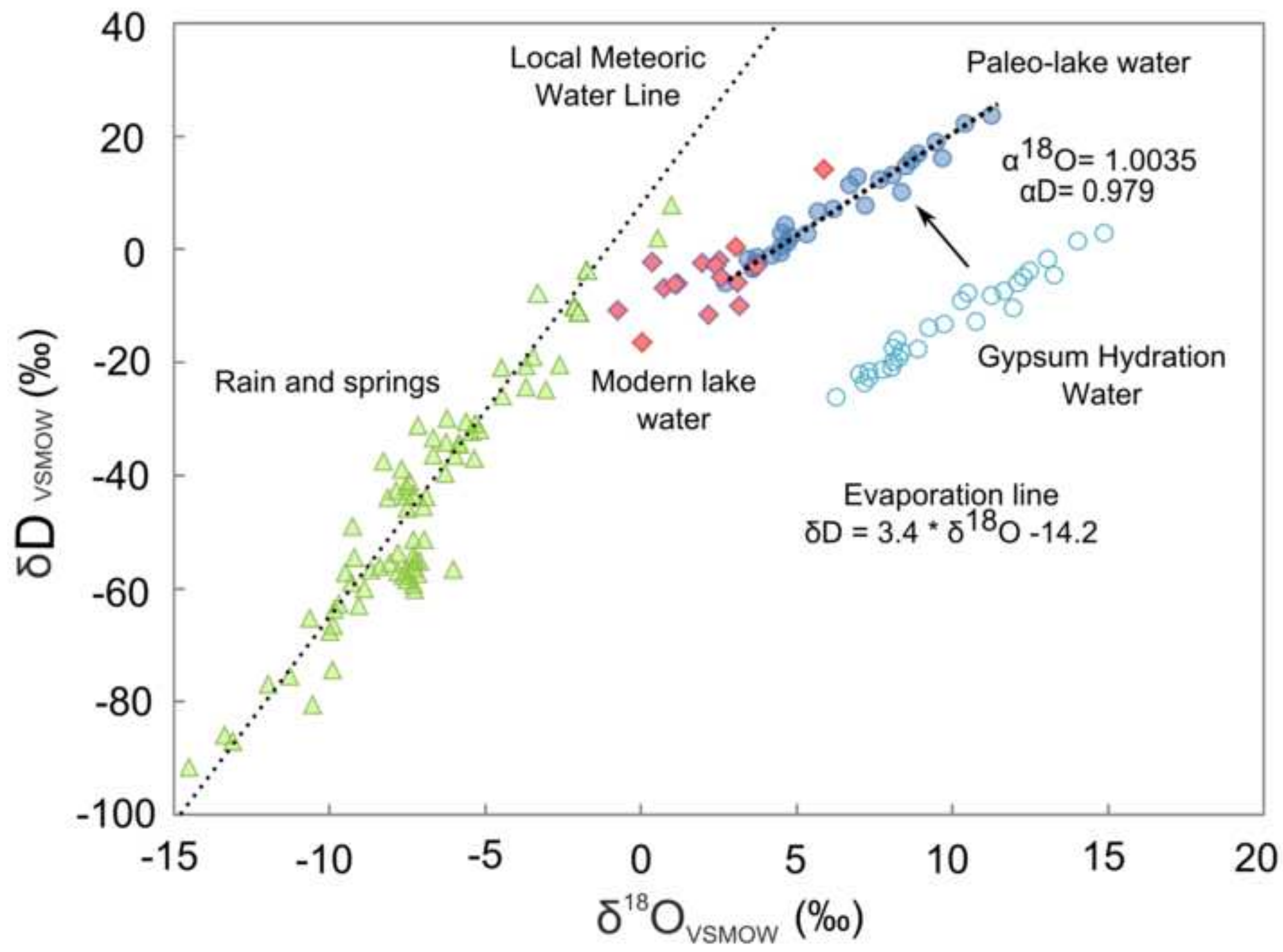



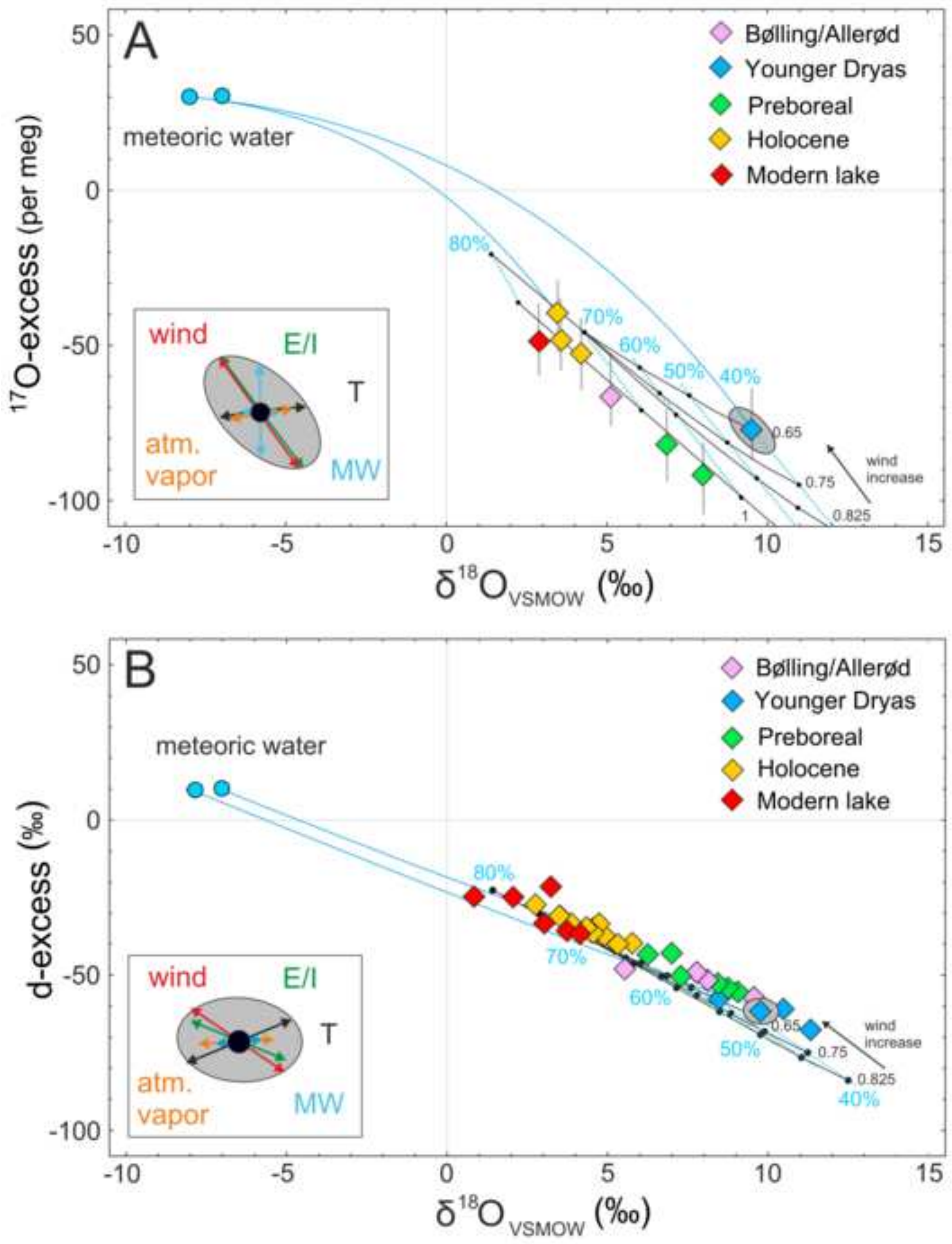

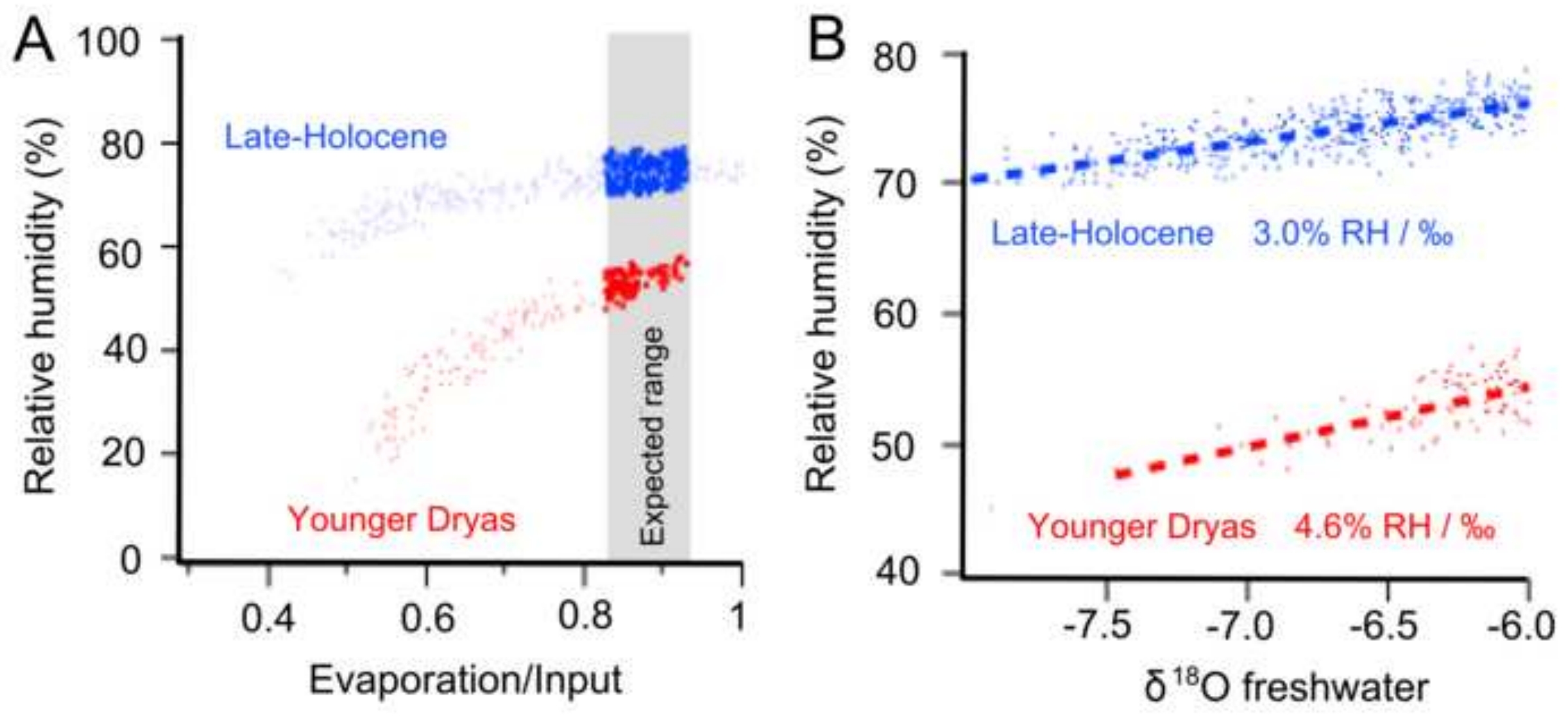


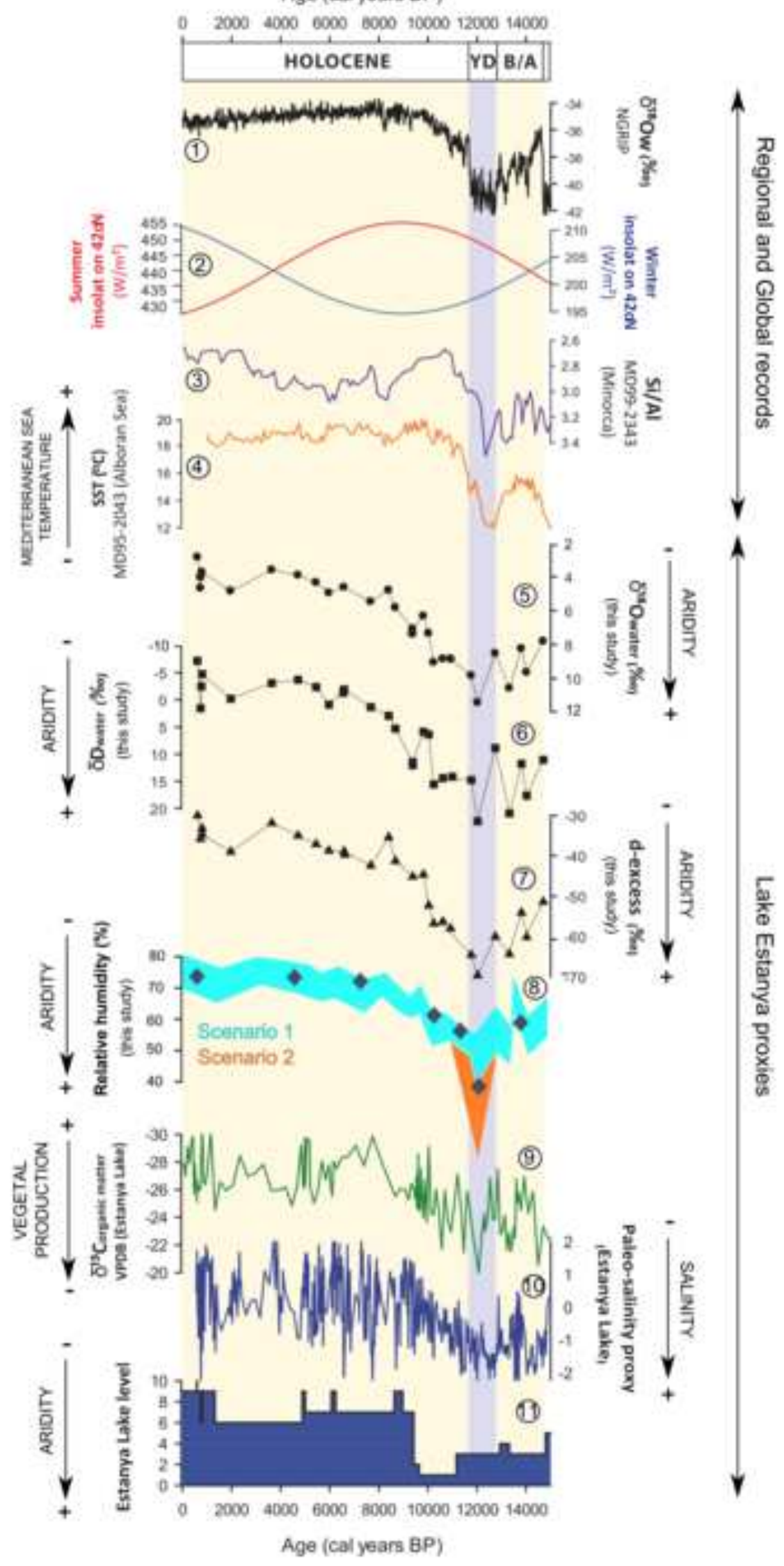



Supplementary material for online publication only
Click here to download Supplementary material for

Click here to download Supplementary material for online publication only: Supplementary material v. final 14-07-17.docx (1) 